\title{
Sprog og identitet: En oversigt
}

\author{
Peter Widell \\ Aarhus Universitet
}

Identitetsbegrebet er i mere end én forstand knyttet til det menneskelige sprog. Et velkendt eksempel på en overvejelse over sammenhængen mellem sprog og identitet finder vi hos Gottlob Frege (2002a (1892)) i hans forsøg på at grundlægge moderne semantik gennem sit berømte eksempel med Morgenstjernen og Aftenstjernen, hvor han viser, at det at kende til, hvad de to navne refererer til, ikke er nok til at fastslå, at referenterne $\mathrm{i}$ verden er identiske (nemlig i dette tilfælde planeten Venus). Ud over en referent, det, der peges på, har vi nemlig også altid en mening i form af en givethedsmåde for referenten (som her er henholdsvis himlen om morgenen og himlen om aftenen). Et andet velkendt eksempel på et møde mellem sprog og identitet, som man i denne sammenhæng kan nævne, er Jacques Derridas fejrede, men samtidig omstridte forsøg på at dekonstruere enhver form for identitetstænkning (Derrida 1970 (1967)).

Netop disse to eksempler illustrerer på bedste vis spændvidden i synet på forholdet mellem sprog og identitet, sådan som det er kommet til udtryk op gennem forrige århundrede. I det første tilfælde er referencen til verden og det klare meningsindhold det, der giver sproget sin faste identitet. I det andet tilfælde opfattes denne identitet kun som noget tilsyneladende, da den i virkeligheden må ses som et mere eller mindre bedragerisk produkt af en stadig forskelsdannelse i sproget.

Inden for psykologien spiller forholdet mellem sprog og personlig identitet en ikke uvæsentlig rolle. Siden René Descartes har begrebet om personlig identitet været knyttet tæt sammen med den menneskelige refleksionserfaring og med evnen til at skabe sammenhæng og enhed i perception, handling og tænkning (Descartes 1967 (1637)), jf. fx også Immanuel Kants begreb om apperceptionens transcendentale syntese (Kant 2002 (1781)) og Georg Wilhelm Friedrich Hegels begreb om den subjektive ånd (Hegel 2005 (1807)). Begge steder er der tale om be- 


\section{Peter Widell}

greber, der peger på en enhedsstiftende identitet bag subjektets enkeltydelser, sådan som de kommer til udtryk i perception, handling, tanke og tale: I Kants tilfælde er identiteten universel, i Hegels tilfælde er identiteten blot historisk og kontingent.

Ligesom begrebet om sprog og personlig identitet har spillet en stor rolle i psykologien, har begrebet om social identitet spillet en tilsvarende stor rolle i sociologien. Her har det været en grundfæstet opfattelse, at det ikke vil være muligt at reducere det sociale til det psykiske. Tværtimod må et samfund opfattes som mere end blot summen af dets enkelte medlemmer: Samfundet, kulturen, sproget, det, Hegel kalder den objektive ånd, er i virkeligheden en overgribende identitetssattende instans på tvoers af alle samfundsmedlemmernes individuelle psykiske akter. Denne tanke kan også ses hos Karl Marx (1974 (18571858)), jf. fx det marxske klassebegreb, ligesom påstanden stadig danner udgangspunkt for en stor del af de systemiske og funktionalistiske tilgange til studiet af social identitet, der længe har været fremherskende inden for sociologien (Émile Durkheim 2005 (1895); Bronislaw Malinowski 2014 (1922); Parsons 1961 (1937); Luhmann 2000 (1984)).

Et vigtigt træk ved diskussionen af de to identitetsbegreber - det psykiske og det sociale - er den stigende erkendelse af sprogets betydning for de to typer identitet og deres indbyrdes relation. Denne stigende interesse kan vi finde i filosofien op gennem hele forrige århundrede. Det er ikke uden grund, man her har talt om et veritabelt "linguistic turn" (Gustav Bergman 1960; Richard Rorty 1992 (1967)). Her kan sprogliggørelsen af det psykiske og det sociale registreres stort set inden for alle toneangivende filosofiske og videnskabsteoretiske strømninger op gennem århundredet: inden for pragmatisme og symbolsk interaktionisme (Charles Sanders Peirce 1997 (1903)); John Dewey 1948 (1920); George Herbert Mead 2005 (1934)), inden for eksistensfanomenologi og filosofisk hermeneutik (Martin Heidegger 2007 (1927), 1996 (1959); Hans-Georg Gadamer 2004 (1960)), inden for kritisk teori, strukturalisme, poststrukturalisme og diskursanalyse (Jürgen Habermas 1970 (1968); Karl-Otto Apel 1971 (1968)); Jacques Lacan 1973; Michel Foucault 2005 (1969)) og inden for analytisk filosofi (Ludwig Wittgenstein 1963 (1923), 1971 (1953); Peter F. Strawson 1959, 1997; Saul Kripke 1980; Harold W. Noonan 2003 (1989), John Perry 1975, 2002; Donald Davidson 1984, 2001; Derek Parfit 1976, 1984; Sidney Shoemaker \& Richard Swinburne 1984; Galen Strawson 2005). Alle disse steder spiller en opmærksomhed omkring sproget en afgørende rolle for studiet af menneskets psykiske og sociale identitet. 
Det har også afspejlet sig i den mere empiriske udforskning af det psykiske og sociale, fx inden for den udviklingspsykologiske forskning, hvor et relativt sprognegligerende studie af handlingen og perceptionen hos det enkelte individ (Piaget 1953 (1936); Piaget \& Inhelder 1971 (1966)) er blevet afløst af studier, der i langt højere grad betoner sprogets og det sociales rolle $i$ dannelsen af det enkelte individs personlighed (Lev Vygotsky 1974 (1934); Jerome S. Bruner 1975, 1976, 1983; Elizabeth Bates 1976, 1979; Michael Tomasello 1999, 2003, 2014).

At det har været muligt at bringe det psykologiske så tæt op ad det sociologiske, som det faktisk er sket, skyldes ikke mindst, at man op gennem forrige århundrede i stigende grad er blevet opmærksom på sprogets kommunikative og diskursive funktioner - til forskel fra de rent grammatisk-syntaktiske strukturer (Ferdinand de Saussure 1970 (1916), Louis Hjelmslev 1976 (1943)); Noam Chomsky 1957, 1965, 1977 (1975)) eller de mere verdensafbildende funktioner (Frege 2002a (1892), 2002b (1918-1919); Bertrand Russell 1905; Rudolf Carnap 1937 (1934), 1959; Kripke 1980; Davidson 1984).

Mere eller mindre socialkonstruktivistiske tilgange begynder at vinde indpas, især henimod slutningen af århundredet. Som prototypisk repræsentant for denne udvikling kan nævnes Habermas, der med baggrund i sin specialudviklede version af talehandlingsteorien (John L. Austin 1997 (1962); John R. Searle 1971 (1965), 1969) i store dele af sit forfatterskab slet og ret ser socialisering og individuering som i virkeligheden to sider af samme sprogformidlede sag (Habermas 1976b): Ud fra sit såkaldte formalpragmatiske program forsøger han at forsvare en universalistisk variant af socialkonstruktivismen, som med træk lånt fra Kants transcendentalfilosofi - og i et opgør med Chomskys rent syntaktisk orienterede universalisme (Habermas 2001 (1971), 1981c (1976)) - vender sin brod mod relativismen i psykologi og sociologi (Habermas 1981a, 1981b; se hertil også Karl-Otto Apel 1973a, 1973b).

Hovedtendensen inden for socialkonstruktivismen synes dog at være, at man lægger sig mere op ad Hegels begreb om den objektive ånd og vælger netop mere relativistiske varianter, hvor den menneskelige psykiske og sociale identitet ses forankret i det lokale og altid (blot) historisk givne. Her danner inspirationen fra Sapirs og Whorfs sprogstudier og deres heraf afledte teser om sproglig relativitet (Edward Sapir 1921; Benjamin Lee Whorf 1956) et vist udgangspunkt, men ikke mindst Peter L. Berger \& Thomas Luckmanns værk The Social Construction of Reality (1976 (1967)) er stadig det kompas, de fleste vælger at styre efter i dag. Af centrale socialkonstruktivister kan nævnes Ken- 
neth Gergen (1991, 1999) og Judith Butler (1990 (2011), 1997). Også påvirkningen fra Foucault og fra kritisk diskursanalyse (Foucault 1971 (1968), 2005 (1969)) spiller en afgørende rolle, lige som det gør det hos Teun van Dijk (1996a, 1996b) og Norman Fairclough (2001 (1989)), hvor mere lingvistisk baserede diskursanalytiske undersøgelser bringes sammen med den kritiske diskursanalyses genealogiske og kausalforklarende forklaringer $\mathrm{i}$ et forsøg på at forholde sig ideologikritisk til moderniteten og det postmoderne samfunds institutioner og tekster.

En overvejende relativistisk position finder vi også inden for sociolingvistikken og konversationsanalysen. Sociolingvistikkens første metodologiske orientering er (mere eller mindre selverklæret) empiristisk, idet man her overvejende beskæftiger sig med etableringen af stabile korrelationer mellem registrerbare grammatiske og sociale variable (William Labov 1969, 1972). Den samme empiricisme finder vi i konversationsanalysen (Harvey Sacks, Emanuel A. Schegloff, \& Gail Jefferson 1974; J. Maxwell Atkinson \& John Heritage 1985; Paul Drew \& John Heritage 1993; Ian Hutchby \& Robin Wooffitt 2008 (1998); Bethan Benwell \& Elizabeth Stokoe 2010 (2007); Jack Sidnell \& Tanya Stivers 2012), selv om udgangspunktet her er mere fænomenologiskdeskriptivt i kraft af påvirkningen fra socialpsykologi (Alfred Schutz 1973 (1932)), mikrosociologi (Ervin Goffman 1959), etnometodologi (Aaron V. Cicourel 1964; Alan Garfinkel 1967) og grounded theory (Barney Glaser \& Anselm Strauss 1967).

Både i sociolingvistikken og i konversationsanalysen har man i de senere år i stigende grad valgt at betone den sociale konteksts resistens over for forsøg på at opløse den i simple faktorer. Inden for sociolingvistikken er statistisk faktoranalyse i vid udstrækning om ikke blevet afløst af, så dog suppleret med discipliner som bl.a. filosofisk hermeneutisk (Gadamer 2004 (1960)) og dybdehermeneutisk tolkningsteori (Habermas 1981c (1970); Alfred Lorenzer 1972, 1973, 1974; i denne sammenhæng kan også nævnes interessen for Pierre Boudieus habitusbegreb, jf. Boudieu 2005 (1977); 1995 (1987); 2009 (1994)), narratologi (George Labov \& Joshua Waletski 1967; J. Maxwell Atkinson \& John Heritage 1985; Bruner 1991; 1996; Giles, Coupland \& Coupland 1992; Michael Bamberg 1997; Deborah Schiffrin 2006), talehandlingsteori og kommunikationslogik (Grice 1989 (1975); Searle 1979a (1975); Stephen C. Levinson 1986, 2000; Leech 1988 (1983); Brown \& Youle 1983; Dan Sperber \& Deirdre Wilson 1986; Penelope Brown \& Stephen C. Levinson 1987; Herbert H. Clark 1996; Francois Recanati 2003, 2011; Peter Grundy 2008 (1995); Billy Clark 2013), magtanalyse 
(Foucault 2001 (1994), Antonio Gramsci 1991 (1927-1937); Ernesto Laclau \& Chantal Mouffe 1997 (1985); Kreps 2015) og retorik (Herbert W. Simons 1988a, 1988b, Norman Fairclough \& Isabella Fairclough 2014) i bestræbelserne på at belyse, hvordan mennesket i sociale grupper til stadighed skaber nye selvbilleder gennem interaktion og samtale.

En afgørende nyorientering inden for forskningen i personlig og psykisk identitet har i de seneste årtier vist sig på baggrund af nyudviklinger inden for kognitiv lingvistik og semantik (George Lakoff \& Mark Johnson 2002 (1980); George Lakoff 1987; Jerry A. Fodor 1975, 1987, 2010 (2008); Ray Jackendorff 1985 (1983); Charles J. Fillmore 1985, 1988; Ronald W. Langacker 1987, 1991; Adele Goldberg 1995; Gilles Faucounier 1994 (1985), 1997; Leonard Talmy 1988, 2000; Gilles Faucounier \& Mark Turner 2003; Tomasello 2003; William Croft \& D. Alan Cruse 2004; Mark Johnson 2007; D. Geeraerts \& H. Cuyckens 2007; Thomas Hoffmann \& Greame Trousdale 2013) og kognitiv og lingvistisk orienteret neurovidenskab (fx Damasios neurofysiologiske teori om forholdet mellem emotion og kognition (Antonio R. Damasio 1994) og Rizzolattis spejlneuronteori om immitativ læring (Giacomo Rizzolatti \& Laila Craighero 2004)). Det er for tidligt at spå om resultatet af disse nyorienteringer.

Et vigtigt aspekt er dog, at man i forbindelse med de filosofiske overvejelser i den anledning på det seneste fra filosofisk hold er begyndt at stille spørgsmålstegn såvel ved den mere naturvidenskabeligt anlagte kognitions- og neurovidenskab som ved de tidligere nævnte mere radikale empiristiske varianter af den sprogbaserede socialkonstruktivisme. Det er her synspunktet blandt disse filosoffer, at menneskelig tænkning, sådan som den kommer til udtryk i perception og handlen, fra bunden af må grundlægges som et strikt normativt funderet anliggende, og at sproget og kommunikationen i stedet for at blive set som en en gang for alle etableret sui generis-sammenhæng - hvadenten den nu tænkes som en universel grammatik i form af en specifik medfødt "language acquisition devise" (Chomsky 1965:25; Fodor 1975; Stephen Pinker 1994), et "Language-of-Thought" (Fodor 1975), der henter inspiration i den sapir-whorfske sproget-determinerer-tanken-opfattelse, eller den antager skikkelse af en radikal sociologistisk tolkning af Wittgensteins tese om, at "Mit sprogs grænser betyder min verdens grænser" (Wittgenstein 1963 (1923):107) - i stedet må ses som i højere grad byggende på præ-sproglige, rent kognitive forudscetninger, sådan som de allerede foreligger i den præsproglige perception og handlen (Dummett 1975, 1976; Gareth Evans 1982; John McDowell 1994, 1998, 1999, 2011; 
Searle 1983; Scott Soames 2010a, 2010b; Christopher Peacocke 1983, 1986, 1992, 2003, 2014; Thomas Scanlon 2014). Det betyder dog ikke, at man ikke blandt mange, ja vel de fleste, af disse filosofiske normativister finder det væsentligt at bevare en grundloeggende naturalisme, således at selvom det normative ikke i begrebslig forstand kan reduceres til det ikke-normative og kausale, så kan det forhold, at et subjekt ved en given lejlighed forvalter denne normativitet, godt belyses tingsligt og kausalt. Her har Davidson med sit begreb om anomal monisme (Davidson 2001 (1970)) søgt at specificere den mest forudsætningsløse ramme for tænkning omkring en sådan ontologisk reduktion af handleverden til kausalverden.

Er denne normative kognitivisme korrekt, betyder det, at det menneskelige sprog som udtryksbåret sprogsystem må tildeles en langt mere beskeden rolle, end det har været almindeligt at gøre det inden for 1900-tallets strukturalisme og poststrukturalisme. Da Saussure i 1900-tallets start (Saussure 1970 (1916)) grundlagde den strukturalistiske betragtningsmåde på sproget, blev den lanceret som et samtidigt angreb på, hvad Saussure kaldte nomenklatur-opfattelsen af sproget, dvs. den holdning at de sproglige udtryk stort set kan betragtes som etiketter påklistret den sprogløse henvisning til tingene (en holdning, der bl.a. kan føres tilbage til John Stuart Mill (2012 (1843))). Men nu er man faktisk blandt mange filosofiske narrativister tilbøjelig til at se netop sådan på det: I stedet for at se sproget på strukturalistisk vis som en konstituerende indfatning af det sproglige tankeindhold, ser man det nu omvendt som primært eksisterende i perception og handlen før sproget som system. Og det vil så sige, at hvad sprogsystemet angår, er det - pace Saussure - i virkeligheden blot en nomenklatur.

Men den nye holdning indebærer også, at der må gøres op med et af de mest grundlæggende principper inden for formel sprogvidenskab og logik siden Frege (1977 (1879)), nemlig kompositionalitetsprincippet, dvs. princippet om, at de sproglige udsagn og propositioner skal ses som en funktion af frit kombinerbare ord og sætninger. Nu viser det sig, at man $i$ et opgør med dette princip synes at kunne gå to veje: (A) Man kan opgive ethvert meningsbegreb og alene operere med et immanent sandhedsbegreb, hvor "p er sand" og "p" opfattes som ækvivalente udtryk (Frank P. Ramsay 1927). En sådan deflationisme, som positionen kaldes, mener ovennævnte filosofiske normativister dog repræsenterer en for radikal løsning. Også Davidsons forslag om at forsyne deflationismen med en transcendentalfilosofisk overbygning $i$ form af en grundlægning af begrebet om sandhed gennem såkaldte T-sætninger - 
sætninger af typen "'Sneen er hvid' er sand, hvis og kun hvis sneen er hvid" - (Davidson 1984 (1967)) mener de filosofiske normativister at måtte forkaste som for radikalt et forslag. Sproget kan ikke blot forstås som et samlet syntaktisk net spændt ud over alle de konkrete situationer, vi bruger sproget til at referere til verden $i$. Et sådant sprog vil det fx være vanskeligt at forestille sig muligt at lære (Dummett 1975, 1976). Her mener man snarere, man bliver nødt til at se sproget som bestående af mere lokale korrespondenser mellem udtryk og indhold. (B) Men det er netop her - det er i hvert fald ovennævnte filosofiske normativisters mening - at vores præ-sproglige og præ-sociale - perception og handlen gennembryder den falske modstilling af sprogtotalitet på den ene side og verden på den anden side, kompositionalitetsprincippet er udtryk for. Man må re-installere sandhedsbegrebet og begrebet om mening som sandhedsbetingelse, men nu ikke i et eller andet fuldt færdigt sprogsystem eller i en eller anden sproglogisk form: Den præsproglige perception og handlen er faktisk fuldt ud i stand til at danne en præsproglig matrice for, hvordan sproglig reference og mening $i$ almindelighed skal se ud: Perception er rettethed mod verden ud fra et bestemt perspektiv. Men det er netop, hvad vi finder gentaget i (a) den sproglige reference - eksemplarisk repræsenteret gennem pegningen og egennavnet - (b) den sproglige meningstilskrivning - det, at prædicere "Solen er gul" om den gule sol, "Himlen er blå" om den blå himmel og "Græsset er grønt” om det grønne græs - og (c) den sproglige sandhedstilskrivning - det, at disse sætninger i bestemte situationer er sande om, hvordan det forholder sig i verden.

Det er så her diskussionen om sproget og handlingen og de to instansers placering $\mathrm{i}$ forhold til hinanden i forbindelse med den menneskelige identitetsdannelse - individpsykologisk og socialt - befinder sig i dag. Her udfolder den sig hovedsagelig som en diskussion om, hvor meget af sproget, der er semantik, dvs. bestemt af sprogets almene form og kompositionalitetsprincippet, og hvor meget af det, der er pragmatik, dvs. bestemt af de konkrete sprogbrugssituationer, det bliver anvendt $i$, og som derfor ikke vil kunne underlægges dette semantiske princip. Alle sprogfilosoffer og lingvister er for så vidt enige om, at kompositionalitetsprincippet må opgives som generelt princip for sproglig mening. Men mens nogle, de såkaldte semantiske minimalister, mener, at væsentlige dele af sproget stadig må kunne analyseres som værende præget af en kompositionel semantik, nemlig alle de dele, der ikke er indeksikaliseret, dvs. bundet til en semantik, der refererer til kontekstuelle omstændigheder i talesituationen (Kaplan 1989; Emma 


\section{Peter Widell}

Borg 2004; Herman Cappelen \& Ernie Lepore 2005), mener andre, de såkaldte kontekstualister, at konteksten i større eller mindre omfang er bestemmende for det tankeindhold eller den proposition, der formidles i den konkrete talesituation (Charles Travis 1986; Searle 1979b (1975), Recanati 2003, 2011; Kent E. Bach; Kepa Korta \& John Perry 2011; John Macfarlane 2014). (For antologier med bidrag fra begge lejre, se Zoltán Gendler Szabó 2005; Gerhard Preyer \& Georg Peter 2005, 2007).

Striden mellem de mere system-konservative semantiske minimalister og de mere radikal-pragmatiske kontekstualister står helt central i den sprogfilosofiske og lingvistiske debat i dag. Debatten tager sit udgangspunkt i Grices epokeskabende kooperationsprincip for bogstavelig kommunikation (Grice 1989 (1975)), ifølge hvilket enhver bogstavelig kommunikation skal være tilrettelagt ud fra hensynet til maksimerne for informativitet (quantity), sandfærdighed (quality), relevans (relation) og korrekthed (mode). Begge fløje accepterer for så vidt princippet (men ikke nødvendigvis alle maksimerne, cf. fx Sperber \& Wilson 1986). Uenigheden derimod går på, hvor bredt man mener kooperationsprincippet kan bringes i anvendelse: Mens de semantiske minimalister mener, at en situeret sætnings semantiske indhold normalt er tilstrækkeligt til at bestemme den indeholdte propositions sandhedsværdi, mener kontekstualisterne omvendt, at der ud over et semantisk indhold også må kræves slutninger af forskellig art - såkaldte eksplikaturer (Sperber \& Wilson 1986) - udløst af Grices kooperationsprincip for at komme fra sætningens semantiske indhold til propositionens sandhedsværdi. Fx kan vi finde et stridspunkt mellem minimalister og kontekstualister i en analyse af en sætning som "Jens er stærk." Her kan propositionens sandhedsværdi ifølge kontekstualisterne ikke bestemmes alene på baggrund af ordenes semantik. Sandhedsværditilskrivningen kræver, at man ud over kendskab til det semantiske indhold også må gøre brug af forskellige ikke-semantisk baserede slutninger, alt afhængig af talesituationen. Fx vil "stærk" have forskellig betydning, alt eftersom ordet bruges om en toårig dreng eller om en sumobryder.

Diskussionen mellem minimalister og kontekstualister er kompleks, men den er samtidig af yderste væsentlighed for afgørelse af spørgsmålet om, hvor grænserne går for menneskets sproglige identitet. De grænser, der er defineret af semantikken, det bogstavelige sprog, afskærmet af det griceske kooperationsprincip, er nemlig afgørende forskellige fra de grænser, der er defineret ved pragmatikken, som skal findes i handlingen, altså "før" eller "efter" den bogstavelige kommuni- 


\section{Sprog og identitet: En oversigt}

kation. Det bliver særlig tydeligt, når man stiller sig spørgsmålet - ikke om forholdet mellem sætning og proposition i forskellige sprogbrugssituationer, sådan som der overvejende er tale om i ovennævnte diskussion - men om, hvordan det allerførst er muligt at danne sproglige sætninger forsynet med propositionelt indhold. Her kræves en filosofisk(re)konstruktiv teori om menneskesprogets opståen, fylogenetisk som ontogenetisk (som basis og udgangspunkt for en tilsvarende empirisk teori om denne udvikling). Men her er vi så atter tilbage ved den menneskelige præsproglige perception og handlen og ved den problematik, Dummett, Evans, McDowell m.fl. har rejst, jf. ovenfor. Hvis vi stadig skal være afvisende over for strukturalistiske, rent syntaktistiske eller sociologistiske bud på, hvad sproget kan være, må udgangspunktet i stedet skulle findes i den normative sammenhæng, den menneskelige instrumentelle handling udgør. Det må være i denne sammenhæng, hvor vi grundlæggende lærer vores verden at kende - også naturens kausale verden - at sproget skal finde sin oprindelse. Men her har vi nu inden for de senere år været vidne til en interessant diskussion om, hvordan det har været muligt at nå herfra - fra perception og handlen - til dét fuldt udfoldede menneskesprog, vi for en stor del definerer os selv som mennesker igennem. Blandt toneangivende personer i debatten herom har man kunne finde filosoffer som Margaret Gilbert (1992 (1989), 2013), Michael Bratman (1999, 2007, 2014), Raimo Tuomela $(1984,2000,2014)$ og Searle $(1995,2010)$. Især Tomasello $(1999,2008$, $2009,2014)$ har tiltrukket sig stor opmærksomhed. Det interessante ved Tomasello er, at han søger at parre filosofiske studier, for en stor del inspireret af studiet af flere af ovennævnte personer, med indgående empiriske studier af chimpanser og børn. Et vigtigt spørgsmål i den forbindelse er spørgsmålet om, hvad overgangen fra ren instrumentel handlen - det at drikke et glas vand, det at skifte gear i en bil eller det at bygge et hus - til social handlen, heri inkluderet beherskelsen af det menneskelige sprog, indebærer. Er der tale om en jævn overgang - det er fx Bratmans synspunkt, $i$ hvert fald for visse simple sociale aktiviteters vedkommende - eller er der snarere tale om forekomsten af en helt ny type handling, en sui generis, sådan som Gilbert, Tuomela, Searle og Tomasello mener det?

Vanskeligheden for alle er at overskride det individuelle, den ensomme handlens, niveau uden at blive nødt til at postulere eksistensen af hypostaserede sociale agenter - universiteter, klasser, regeringer, virksomheder - der ikke kan finde forankring i den enkelte handlendes bevidsthed (hvilket ifølge ovennævnte forskere vil være udtryk for en 


\section{Peter Widell}

sociologistisk forkortet fejltagelse). Alle er enige om, at simple former for interaktion, sådan som vi fx finder det i krig og spil eller i forskellige former for kooperativ handlen, ikke vil kunne gøre det ud for egentlig social handlen. Således er det fx Searles opfattelse, som vi vil koncentrere os lidt om i det følgende, at social handlen herudover må kræve mindst (1) kollektiv intentionalitet - det må være et vi og ikke et aggregat af jeg'er, der handler (som Toumela har redegjort for det med sit begreb om we-mode joint intentionality) - (2) kommunikative dobbeltintentioner - afsender må ikke alene have intentionen om at gøre modtager opmærksom på et eller andet, han må også have intentionen om gøre modtager opmærksom på, at det netop er hans intention at vække den første type opmærksomhed (dette begreb låner Searle fra Grice (1989 (1957)) - samt (3) kendskab til, hvordan man opretter og bruger statusfunktioner - funktioner, hvor en bestemt handling, fx brugen af en underskrift, knytter visse tilladelser, påbud eller forbud til sig.

Mens (2) for Searle blot vil være en kompleks form for instrumentel handlen, forekommer det ifølge Searle ikke muligt at reducere (1) og (3) til en sådan type handlen (hvilket ikke betyder, at Searle, som den realistiske naturalist, han er, udelukker muligheden for en egentlig ontologisk reduktion).

Men det vil sige, at (2) og (3) ifølge Searle samlet repræsenterer en egentlig ny form for handlen, en handlen, som ikke er sammenfaldende med social handlen i almindelighed, men som ikke desto mindre udgør en væsentlig del af den. Denne type social handlen giver Searle betegnelsen institutionel handlen. En interessant følge af specielt (3) er, at vi herigennem får et klart indblik i menneskets sociale retsorden, dets deontologi, som Searle kalder det med særlig reference til Kant, og derigennem i væsentlige etiske forhold omkring menneskelig social handlen: Statusfunktioner som underskrifter, giftermål og forretningskontrakter vil kun have gyldighed, i den udstrækning de følges af de deltagende parter. Men det betyder, at ethvert menneskeligt fællesskab som den deontologiske orden, det må vare, kun vil kunne opretholde sin identitet som fællesskab, ved at dets enkelte medlemmer accepterer og respekterer dem. Det lægger omvendt et normativt pres på fællesskabets enkelte medlemmer: Hvis et medlem vil tilhøre dette fællesskab, må han eller hun indordne sig under den deontologiske orden, der hersker her.

$\mathrm{Nu}$ er det klart, at det normative pres, der ifølge Searle ligger på fællesskabets enkelte medlemmer ved social handlen, også ligger på fællesskabets enkelte medlemmer ved egentlig sprogbrug. Searle synes 
selv at være lidt uklar omkring sprogets rolle og placering inden for det menneskelige sociale fællesskab: Er sproget en social institution på linje med andre sociale institutioner, eller er det en overordnet institution, som danner forudsætning for alle andre sociale institutioner? Der synes at være fordele ved at se på sproget som blot én blandt mange sociale institutioner. Det giver os nemlig en mulighed for at definere sprogbrug som slet og ret den underform for institutionel handlen, der specielt knytter de tanker eller propositioner til sig, som vi i første instans kender fra vores umiddelbare perception og handlen i verden. Eller kort: Tale vil da slet og ret kunne opfattes som tanker båret af statusfunktioner: Et eksempel fra Tomasello kan belyse dette (Tomasello 2014:67; eksemplet her er lettere modificeret i forhold til Tomasello): Har jeg ved en given lejlighed set en hugorm bag en sten og vil gøre min makker opmærksom på dette forhold, kan jeg gøre det enten ved at vise ham hugormen bag stenen eller ved at sige "Der er en hugorm bag stenen". Vælger jeg nu det sidste, vælger jeg at bruge udtrykket "Der er en hugorm bag stenen" som led i en statusfunktion, som binder tanken om, at der er en hugorm bag stenen, til dette udtryk. Nu er denne tanke selvfølgelig kompleks: Ligesom perceptionen eller forventningen om, at der er en hugorm bag stenen, involverer dels en fokusering $p a ̊$ hugormen og stenen, dels en opmoerksomgørelse på deres indbyrdes relation i situationen, rummer den tilsvarende udtale af sætningen såvel en referencehandling som en prædikationshandling. Nu er reference og prædikation ikke simple og instrumentelle, sådan som perceptuelle handlinger er det. Ikke desto mindre synes der at kunne etableres en bro fra perceptionens instrumentelle kontekst til talens sociale og institutionelle kontekst. Men hvordan?

Lad os se på referencehandlingen og prædikationshandlingen $\mathrm{i}$ tur og orden: Her må referencehandlingen ses som den simpleste handletype: At referere består i at pege på noget for nogen, dvs. gøre det til fælles emne eller topos i samtalesituationen; men det kræver blot den form for socialitet, vi finder i det searlske handletype (2) ovenfor. Pegning kan med andre ord ikke betegnes som nogen institutionel handling. Hvad prædikationshandlingen derimod angår, er forholdet lidt mere kompliceret. At prædicere noget om noget udpeget består egentlig $i$ at demonstrere, at den situation, den udpegede genstand indgår i, i en vis henseende ligner en tidligere erfaret situation, hvor denne lighedsrelation er blevet etableret via et pant, som benyttes af taler til over for hører at gøre opmoerksom på, at netop denne situation foreligger. Et sådant pant kunne fx - som i vores eksempel - være et billede af en 
hugorm: jeg peger i retning af stenen og viser den, jeg kommunikerer med, mit billede af hugormen. Men at etablere et sådan pant kræver ikke blot handlen ud fra den searlske handletype (1) ovenfor. For at kommunikationen om hugormen bag stenen skal kunne lykkes, må taler og hører på forhånd have etableret en enighed om, hvad det betyder at præsentere et sådant billede.

Det vil også kunne siges sådan: Der må have været etableret en indføringssituation for billedet, som må have givet de kommunikerende en fælles viden om, hvad billedet toeller som i den aktuelle brugssituation (og i enhver anden brugssituation for billedet) (se for en introduktion af disse to begreber Peter Widell 2009). Men det kræver netop - i modsætning til pegningen - egentlig institutionel handlen, altså handlen ud fra (1) og (3) ovenfor.

$\mathrm{Nu}$ foregår kommunikation normalt ikke i form af fremvisen af billeder. I normal kommunikation benytter vi os af arbitrcere tegn som i sætningen: "Der er en hugorm bag stenen." Og det er så her, strukturalisterne og de semantiske minimalister mener at kunne fremføre deres pointer. Imidlertid belyser billedet langt bedre end talen om et sprogsystem eller en abstrakt logisk form - det vil i hvert tilfælde kunne være kontekstualisternes modpåstand - hvad det vil sige at kommunikere: Meningen eksisterer ikke i et eller andet sprogsystem eller i en eller anden abstrakt logisk form, men i den præ-sproglige perception og handlen. Her kommer det også på mere prægnant vis frem, hvorfor der er så megen pragmatik på spil - fremkaldt af den kommunikationssituationelle kontekst - som betingelse for, at vi kan slutte os til et eventuelt propositionelt indhold: Hugormen i billedet ligner blot hugormen bag stenen. Dvs. der er også altid en række forskelligheder. Men sådanne forskelligheder forsvinder ikke blot fordi tegnet bliver arbi-trært. Sprogsystemet og den logiske form forlener ikke i sig selv det propositionelle indhold med skarphed. Der vil stadig være uklarheder omkring, hvad vi egentlig er blevet enige om $\mathrm{i}$ indføringssituationen, uklarheder som først vil kunne fjernes, når den aktuelle talesituations pragmatik er blevet inddraget, og det propositionelle indhold herigennem er blevet endeligt identificeret.

Det fører os tilbage til diskussionen med de semantiske minimalister. Nu repræsenterer den ovenfor skitserede kontekstualistiske måde at se på sproget på ikke som sådan et angreb på kompositionalitetsprincippet og begrebet om analyticitet, men alene et angreb på forestillingen om, at princippet vil kunne realiseres i en eller anden omfattende forstand garanteret af det syntaktiske og formelle uafhængigt af enhver lo- 


\section{Sprog og identitet: En oversigt}

kal kontekst (jf. Searle 1969:4-12). Det at kompositionalitetsprincippet alligevel vil kunne tænkes som virksomt princip af kontekstualisterne, men at det altså må ske med det forbehold, at vi aldrig fuldt vil kunne realisere princippet i den mangfoldighed af sprogspil, vi indgår i, peger $i$ en interessant forstand tilbage på den universalpragmatik, Habermas lancerer i 1970'erne, og specielt på den distinktion mellem kommunikativ handlen og diskurs, han formulerer i Habermas 2001 (1971). For når man taler om statusfunktioner, kommer man nemlig uvægerligt til at tale om deres etablering (i indføringssituationer) og deres anvendelse (i brugssituationer), og dermed også om muligheden for at ændre disse statusfunktioner løbende, hvis man finder det formålstjenligt for forståelsen på et givet punkt i en samtale. Men det er netop det, Habermas sigter til med sin distinktion mellem kommunikativ handlen og diskurs: muligheden for diskursivt at problematisere de normer og gyldighedsfordringer, man finder utilstrækkelige i den kommunikative handlen, i den hensigt at forbedre dem diskursivt. Men netop her bliver også den deontologiske fordring om at sikre konsistens i den institutionelle handlen i særlig grad synlig.

Måske kan Habermas tanker her råde bod på det princip for det normative område, Searle kan synes at mangle. Under alle omstændigheder vil vi gennem dette begreb kunne pege på en vigtig trefoldig alliance mellem sprog og identitet for mennesket inden for rammerne af et normativt-diskursivt foellesskab, hvor vi til stadighed vil kunne forsøge at forbedre vores talemidler, nemlig dels i relation til den teoretisk-empiriske verden ("Ved hvilken temperatur koger kviksølv?"; "Hvornår startede første verdenskrig?"; "Hvad mente Kierkegaard med sit angstbegreb?), i relation til den tekniske verden ("Kan broen holde ved brug af denne betonblanding?"; "Hvor effektiv er den neo-liberalistiske kur over for Grækenland?") og i relation til den praktisk-etiske verden ("Hvornår må man slå ihjel?"; "Er demokratiet den bedste styreform?").

Habermas mente i sin tid, at det var muligt at udlede en almenetik a la Kant ud fra de formelle udgangsbetingelser, som gælder for samtalen i det normativt-diskursive fællesskab, jf. Habermas' diskursetiske program i Habermas $(1991,1996)$. Det var nok at tage munden for fuld. Men Habermas' delvis strandede projekt forhindrer ikke, at vi i dag - også som sproggranskere - vil kunne påbegynde en refleksion over de etiske fordringer, der ligger i det at føre diskurs om vores sprog og om den del af vores praksis, som vedrører vores sociale institutioner. Findes der faktisk en almenforpligtende sammenhoeng her? 


\section{Peter Widell}

Spørgsmålet involverer også udviklingspsykologiske og pædagogiske aspekter. Her kunne, som Habermas selv er inde på det bl.a. i Habermas 1976b, studiet af den udviklingspsykologiske moralfilosof Lawrence E. Kohlberg (1981a, 1981b, 1984) - men også neo-kohlbergianere som bl.a. Elliot Turiel (1983, 2002;) og Larry P. Nucci (2001) (cf. også antologien Larry P. Nucci \& Darcia Navaez 2008) - danne et passende udgangspunkt.

Med spørgsmålet om, hvorvidt vi som forudsætning for en vederhæftig diskurs vil kunne finde en almenforpligtende etik, er vi for så vidt tilbage ved denne indledende artikels udgangspunkt: Har mennesket et velbegrundbart fællesskab at oparbejde en tilforladelig identitet inden for fx gennem henvisningen til en objektiv realitet af genstande og meningsindhold, sådan som Frege mente det, eller - som vi nu har set det for Habermas' vedkommende - gennem henvisningen til et almentforbindtligt etisk princip for styring af diskurser? Eller er vores sproglige eksistens kendetegnet af en gennemgående relativitet (grænsende til det paradoksale), som vi aldrig vil kunne sikre os et fundament for, sådan som det fx er Derridas opfattelse?

Inden for disse to poler - objektivismens eller universalismens pol på den ene side og relativismens pol på den anden side - har for så vidt al diskussion om forholdet mellem sprog og identitet været spændt ud op gennem hele forrige århundrede og helt frem til i dag. Og det gælder, hvadenten man via denne diskussion har villet finde frem til en identitet, der var biologisk, sociologisk eller individualpsykologisk.

\section{Artiklerne}

De to poler er også mærkbare i de fire bidrag i dette temanummer om sprog og identitet. Mens de to første artikler, Ole Togebys artikel Sprog og Identitet og Christoffer Kølvraas artikel Past and Future in the construction of Communal identity: Collective Memory and Mythical Narratives udelukkende er af generel og begrebsafklarende art, indrager Carsten Stages artikel Socialkonstruktivisme, sprog og identitet: Identitetsforhandlinger på Eva Dien Brine Markvoorts sygdomsblog '65 Red Roses' og Tina Thode Hougaards artikel Bidrag til en karakteristik af identitetskonstruktion på nettet - fra virtuel til medialiseret identitet også empirisk materiale, som begge steder er hentet fra internettet. Alle artikler behandler socialkonstruktivistiske indfaldsvinkler til diskussionen om sprog og identitet, om end de tre første artikler også gør det ud 


\section{Sprog og identitet: En oversigt}

fra en mere eller mindre kritisk stillingstagen til nogle af dens mere radikale teser.

Ole Togebys artikel Sprog og identitet tager udgangspunkt i Berger og Luckmanns bog Den samfundskabte virkelighed, hvor relationen mellem menneske og sprog opfattes som et dialektisk forhold, hvor på den ene side sproget må ses dels (1) (qua ytring) som produkt af menneskelig handling, dels (2) (qua system) som objektiv realitet, og på den anden side (3) den menneskelige sociale orden må ses som et sprogligt produkt, og ikke blot som en del af tingenes natur. Mennesket har ganske vist også en natur, men denne natur er på grund af sin verdensåbenhed og plasticitet underlagt socialt determinerende påvirkninger i kraft af eksistensen af et menneskeligt sprog. Den menneskelige identitet er derfor spændt ud mellem at være vilkår og skæbne og at være intention og valg.

Christoffer Kølvraas artikel Past and Future in the construction of Communal identity: Collective Memory and Mythical Narratives belyser spørgsmålet om, hvorvidt social identitet er en helt igennem sproglig konstrueret størrelse, sådan som mere radikale konstruktivister hævder. Han eksemplificerer sin belysning ved at se på, hvordan fortiden kan tænkes at indgå i social identitets-konstruktion. Artiklen argumenterer for det synspunkt, at betingelsen for at forstå, hvorfor kollektiv hukommelse og mytisk narrativisering af fortiden danner så kraftfulde elementer i konstruktionen af kollektive identiteter, må være, at man sørger for at skelne klart mellem en sådan konstruktion og historiografisk videnskab. Her må kollektiv hukommelse ses som en særlig slags mytedannende diskurs, som har ganske lidt at gøre med den historiske virkelighed, historiografien tager sig af. Det er klart, at Christoffer Køvraa med sit synspunkt, signalerer en kritisk distance til i hvert fald mere radikale varianter af socialkonstruktivismen.

Carsten Stages artikel Socialkonstruktivisme, sprog og identitet: Identitetsforhandlinger på Eva Dien Brine Markvoorts sygdomsblog '65 Red Roses' lægger ligeledes kritisk distance til de mere radikale varianter af socialkonstruktivismen. Socialkonstruktivismen hylder ifølge Carsten Stage en form for begrebsrelativisme, hvor det hævdes, at virkeligheden skabes af vores begreber. Dette synspunkt, sådan som det bl.a. kan findes hos Michel Foucault, Ernesto Laclau og Chantal Mouffe, Judith Butler, Stuart Hall, Karl Popper og Richard Jenkins, vil Carsten Stage gerne gøre op med. I stedet vil han forslå, at man skelner mellem forskellige former for, eller grader af, konstruktivisme. Hvordan det kan gøres, belyses i artiklen, bl.a. via inddragelse af analysen 
af en mediecase - Eva Dien Brine Markvoorts sygdomsblog 65 Red Roses.

Tina Thode Hougaards artikel Bidrag til en karakteristik af identitetskonstruktion på nettet - fra virtuel til medialiseret identitet er, hvad det teoretiske angår, tydeligt inspireret af socialkonstruktivismens teori og metode. Artiklen er en undersøgelse af forskellige eksempler på konstruktion af netidentitet $i$ henholdsvis dansk webchat og på Facebook. Hvor der i chat var meget fokus på leg med køn og identitet, er der på de aktuelle sociale medier i højere grad tale om selvrapportering og selviscenesættelse og på at være anerkendelsesværdig. Artiklen slutter af med at foreslå begrebet "medialiseret identitet" til karakterisering af den type undersøgelse, artiklen er et eksempel på, for at understrege mediernes centrale rolle i den enkelte persons identitetsarbejde.

\section{Litteratur}

Apel, Karl-Otto (1971 (1968)) 'Szientistik, Hermeneutik und Ideologiekritik: Entwurf einer Wissenschaftslehre in erkenntnis-antropologischer Sicht', In: Karl-Otto Apel et al. (ed.) Hermeneutik und Ideologiekritik. Frankfurt/Main: Suhrkamp.

Apel, Karl-Otto (1973a) Transformation der Philosophie, Band I: Sprachanalytik, Semiotik, Hermeneutik. Frankfurt/Main: Suhrkamp.

Apel, Karl-Otto (1973b) Transformation der Philosophie, Band II: Das Apriori der Kommunikationsgemeinschaft. Frankfurt/Main: Suhrkamp.

Atkinson, J. Maxwell \& John Heritage (eds.) (1985) Structures of Social Action: Studies in Conversational Analysis. Cambridge: Cambridge University Press.

Austin, John L. (1997 (1962)) Ord der virker. København: Gyldendal.

Bamberg, Michael (ed.) (1997) 'Narrative Development: Six Approaches. Lawrence Earlbaum

Bates, Elizabeth (1976) Language and Context: The Acquisition of Pragmatics. New York: Academic Press.

Bates, Elizabeth (1979) The Emergence of Symbols: Cognition and Communication in Infancy (Language, Thought, and Culture). New York: Academic Press.

Benwell, Bethan \& Elizabeth Stokoe (2010 (2007)) Discourse and Identity. Edinburgh: Edinburgh University Press.

Berger, Peter L. \& Thomas Luckman (1976 (1967)) Den samfundsskabte virkelighed: En videnskabssociologisk afhandling. København: Lindhardt og Ringhof.

Bergman, Gustav (1960) 'Strawson's Ontology', Journal of Philosophy 57:601-622.

Borg, Emma (2004) Minimal Semantics. Oxford: Oxford University Press. 


\section{Sprog og identitet: En oversigt}

Bourdieu, Pierre (1995 (1987)) Distinktionen: En sociologisk kritik af dømmekraften. Frederiksberg: Det lille Forlag.

Bourdieu, Pierre (2005 (1977)) Udkast til en praksisteori. København: Hans Reitzels Forlag.

Bourdieu, Pierre (2009 (1994)) Af praktiske grunde: Omkring teorien om den menneskelige handlen. København: Hans Reitzels Forlag.

Bratman, Michael E. (1999) Faces of Intention: Selected Essays on Intention and Agency. Cambridge: Cambridge University Press.

Bratman, Michael E. (2007) Structures of Agency: Essays. Oxford: Oxford University Press.

Bratman, Michael E. (2014) Shared Agency: A Planing Theory of Acting Together. Oxford: Oxford University Press.

Brown, Gillian \& George Yule (2003 (1983)) Discourse Analysis. Cambridge: Cambridge University Press.

Brown, Penelope \& Stephen C. Levinson (1987) Politeness: Some Universals in Language Usage. Cambridge: Cambridge University Press.

Bruner, Jerome S. (1975) 'The ontogenesis of speech acts', Journal of Child Language, 2:1-19.

Bruner, Jerome S. (1976) 'From communication to language - A psychological persepctive: Dedicated to Roman Jakobson on his eithieth birthday', Cognition 3, 3:255-287.

Bruner, Jerome S. (1983) Child's Talk: Learning to Use Language. New York: Norton.

Bruner, Jerome S. (1991) 'The Narrative Construction of Reality', Critical Inquiry 18, 1:1-21.

Bruner, Jerome S. (1996) 'A Narrative Model of Self Construction', Psyke og Logos 17, 1:154-170.

Butler, Judith (1997) Excitable Speech: The Politics of the Performative. London: Routledge.

Butler, Judith (2011 (1990)) Gender Trouble: Feminism and the Subsersion of Identity. London: Routledge.

Carnap, Rudolf (1937 (1934)) The Logical Syntax of Language. London: Routledge \& Keagan Paul.

Carnap, Rudolf (1959) Introduction to Semantics. Cambridge, MA: Harvard University Press.

Chomsky, Noam (1957) Syntactic Structures. The Hague: Mouton.

Chomsky, Noam (1965) Aspects of the Theory of Syntax. Cambridge, MA: The MIT Press.

Chomsky, Noam (1977 (1975)) Om sprog. København: Gyldendal.

Cicourel, Aaron V. (1964) Method and Measurement in Sociology. New York: The Free Press.

Clark, Billy (2013) Relevance Theory. Cambridge: Cambridge University Press. 


\section{Peter Widell}

Croft, William \& D. Alan Cruse (2004) Cognitive Linguistics. Cambridge: Cambridge University Press.

Damasio, Antonio R. (1994) Descartes'Error: Emotion, Reason, and the Human Brain. New York: Avon Books.

Davidson, Donald (1984) Inquiries into Truth and Interpretation. Oxford: Clarendon Press.

Davidson, Donald (2001) Subjective, Intersubjective, Objective. Oxford: Clarendon Press.

Davidson, Donald (2001 (1970)) 'Mental Events' in Essays on Actions and Events. Oxford: Clarendon Press:207-224.

Derrida, Jacques (1970 (1967)) Om grammatologi. København: Arena.

Descartes, René (1967 (1637)) Om metoden. København: Gyldendal.

Dewey, John (1948 (1920)) Reconstruction in Philosophy. Boston: Beacon Press.

Drew, Paul \& John Heritage (eds.) (1992) Talk at Work: Interaction in Institutional Settings. Cambridge: Cambridge University Press.

Dummett, Michael (1975) 'What is a Theory of Meaning?', In: Samuel Guttenplan (ed.) Mind and Language; Wolfson College Lectures 1974. Oxford: Clarendon Press.

Dummett, Michael (1976) 'What is a Theory of Meaning? (II)', In: Gareth Evans \& John McDowell (eds.) Truth and Meaning; Essays in Semantics. Oxford: Clarendon Press.

Durkheim, Emile (2005 (1895)) Den sociologiske metodes regler. København: Gyldendal Akademisk.

Fairclough, Isabela \& Norman Fairclough (2012) Political Discourse Analysis: A Method for Advances Students. London: Routledge.

Fairclough, Norman (2001 (1989)) Language and Power. London: Longman.

Fauconnier, Gilles (1994 (1985)) Mental Spaces: Aspects of Meaning Construction in Natural Language. Cambridge, MA: The MIT Press.

Fauconnier, Gilles (1997) Mappings in Thought and Language. Cambridge: Cambridge University Press.

Fauconnier, Gilles \& Mark Turner (2003) The Way We Think: Conceptual Blending And The Mind's Hidden Complexities. New York: Basic Books.

Fillmore, Charles J. (1985) 'Frame Semantics and the Semantics of Understanding', Quaderni di Semantica:222-54.

Fillmore, Charles J. (1988) 'The Mechanisms of 'Construction Grammar", BLS 14:35-55.

Fodor, Jerry A. (1975) The Language of Thought. Cambridge, MA: Harvard University Press.

Fodor, Jerry A. (1987) Psychosemantics: The problem of meaning in the philosophy of mind. Cambridge, MA: The MIT Press.

Fodor, Jerry A. (2010 (2008)) LOT 2: The Language of Thought Revisited. Oxford: Oxford University Press. 
Foucault, Michel (1971 (1968)) 'Diskurs og diskontinuitet', In: Peter Madsen (ed.) Strukturalisme. København: Rhodos: 145-162.

Foucault, Michel (2001 (1994)) Power: Essential Works of Foucault 19541984, Volume 3. Harmondsworth: Penguin.

Foucault, Michel (2005 (1969)) Vidensarkceologien. Århus: Philosophia.

Frege, Gottlob (1977 (1879)) 'Begriffsschrift, a formula language, modeled upon that of arithmetic, for pure thought', In: van Heijenoort, J. (ed.) From Frege to Gödel. Cambridge, Massachusetts: Harvard University Press: $1-82$

Frege, Gottlob (2002a (1892)) 'Mening og betydning', In: Gottlob Frege Filosofiens, sprogets og matematikkens grundlag. Århus: Philosophia:159-182.

Frege, Gottlob (2002b (1918-1919)) 'Tanken', In: Filosofiens, sprogets og matematikkens grundlag. Århus: Philosophia: 219-244.

Gadamer, Hans-Georg (2004 (1960)) Sandhed og metode: Grundtrcek af en filosofisk hermeneutik. Århus: Systime og Arne Jørgensen.

Garfinkel, Harold (1967) Studies in Ethnomethodology. Englewood Cliffs, NJ: Prentice-Hall.

Gergen, Kenneth J. (1991) The Saturated Self: Dilemmas of Identity in Contemporary Life. New York: Basic Books

Gergen, Kenneth J. (1999) An Invitation to Social Construction. London: SAGE Publication.

Geeraerts, Dirk \& Hubert Cuyckens (eds.) (2010) The Oxford Handbook of Cognitive Linguistics. Oxford: Oxford University Press.

Gilbert, Margaret (1992 (1989)) On Social Facts. London: Routledge.

Gilbert, Margaret (2013) Joint Commitment: How We Make the Social World. Oxford: Oxford University Press.

Giles, Howard, Justine Coupland \& Nikolas Coupland (eds.) (1992) Contexts of Accomodation: Developments in Applied Sociolinguistics. Cambridge: Cambridge University Press.

Glaser, Barney \& Anselm Strauss (1967) The Discovery of Grounded Theory: Strategies for Qualitative Research. Chicago: Aldine.

Goffman, Erving (1959) The Presentation of Self in Everyday Life. New York: Anchor Books.

Goldberg, Adele E. (1995) Constructions: A Construction Grammar Approach to Argument Structure. Chicago, ILL: University of Chicago Press.

Gramsci, Antonio (1991 (1927-1937)) Fcengselsoptegnelser i udvalg (2 bind). København: Museum Tusculanum.

Grice, Herbert Paul (1989 (1975)) 'Logic and Conversation', In: Studies in the Way of Words. Cambridge Massachusetts/London, England: Harvard University Press:22-40.

Grundy, Peter (2008 (1995)) Doing pragmatics. London: Edward Arnold.

Habermas, Jürgen (1970 (1968)) Erkenntnis und Interesse. Frankfurt/Main: Suhrkamp. 


\section{Peter Widell}

Habermas, Jürgen (1976a) Zur Rekonstruktion des historischen Materialismus. Frankfurt/Main: Suhrkamp.

Habermas, Jürgen (1976b) 'Moralentwicklung und Ich-Identität', In: Zur Rekonstruktion des historischen Materialismus. Frankfurt/Main: Suhrkamp:63-91.

Habermas, Jürgen (1981a) Theorie des kommunikativen Handelns, Band 1: Handlungsrationalität und gesellschaftliche Rationalisierung. Frankfurt/ Main: Suhrkamp.

Habermas, Jürgen (1981b) Theorie des kommunikativen Handelns, Band 2: Zur Kritik der funktionalistischen Vernunft. Frankfurt/Main: Suhrkamp.

Habermas, Jürgen (1981c (1970)) 'Hermeneutikken krav på universel gyldighed', In: Jürgen Habermas (ed.) Teorier om samfund og sprog: Artikler 1961-76: 69-96.

Habermas, Jürgen (1991) Erläuterungen zur Diskursethik: Philosophisches Aufsätze.

Habermas, Jürgen (1996 (1983)) Diskursetik. Frederiksberg: Det lille forlag.

Habermas, Jürgen (2001 (1971)) 'Forberedende bemærkninger til en teori om den kommunikative kompetens', In: Carol Henriksen (ed.) Can you reach the salt?: Pragmatikkens klassiske tekster. Roskilde: Roskilde Universitetsforlag:137-170.

Hegel, Georg Wilhelm Friedrich (2005 (1807)) Andens fcenomenologi. København: Gyldendal.

Heidegger, Martin (1996) 'Sproget', Slagmark, $n r$. 25:75-92.

Heidegger, Martin (2007 (1927)) Vceren og Tid. Aarhus: Klim.

Hoffmann, Thomas \& Graeme Trousdale (eds.) (2013) The Oxford Handbook of Construction Grammar. Oxford, New York: Oxford University Press.

Hutchby, Ian \& Robin Wooffitt (2008 (1998)) Conversation Analysis: Principles, Practices and Applications. Cambridge: Polity Press.

Jackendoff, Ray (1985 (1983)) Semantics and Cognition. Cambridge Massachusetts: The MIT Press.

Kant, Immanuel (2002 (1781)) Kritik af den rene fornuft. København: Det lille forlag.

Kaplan, David (1989) 'Demonstratives', In: Joseph Almog, John Perry \& Howard Wettstein (eds.) Themes from Kaplan. New York, Oxford: Oxford University Press:481-563.

Korta, Kepa \& John Perry (2011) Critical Pragmatics: An Inquiry into Reference and Communication. Cambridge, New York: Cambridge University Press.

Kohlberg, Lawrence E. (1981a) Essays on Moral Development, Volume 1: The Philosophy of Moral Development. San Fransisco: Harper \& Row.

Kohlberg, Lawrence E. (1981b) The Meaning and Measurement of Moral Development. Massachusetts: Clark Univ Heinz Werner Inst. 


\section{Sprog og identitet: En oversigt}

Kohlberg. Lawrence E. (1984) Essays on Moral Development, Volume 2: The Psychology of Moral Development. San Fransisco: Harper \& Row.

Kreps, David (ed.) (2015) Gramsci and Foucault: A Reassesment. Aldershot, Hampshire: Ashgate.

Kripke, Saul (1980 (1972)) Naming and Necessity. Oxford: Basil Blackwell.

Labov, William (1969) The Study of Non-standard English. Campaign, IL: National Counsil of Teachers of English.

Labov, William (1972) Language in the Inner City. Philadelphia: University of Pennsylvania.

Labov, William \& Joshua Waletzky (1967) 'Narrative Analysis', In: J. Helm (eds.) Essays on the Verbal and Visual Arts. Seattle: University of Washington Press:12-44.

Lacan, Jacques (1973) Det ubevidste sprog. København: Rhodos.

Laclau, Ernesto \& Chantal Mouffe (1997 (1985)) Demokrati og Hegemoni. København: Akademisk Forlag.

Lakoff, George (1987) Women, Fire, and Dangerous Things: What Categories Reveal about the Mind. Chicago \& London: University of Chicago Press.

Lakoff, George \& Mark Johnson (2002 (1980)) Hverdagens metaforer. København: Hans Reitzels Forlag.

Langacker, Ronald W. (1987) Foundations of Cognitive Grammar, vol 1: Theoretical Prerequesites. Stanford: Stanford University Press.

Langacker, Ronald W. (1991) Foundations of Cognitive Grammar, vol 2: Descriptive Applications. Stanford: Stanford University Press.

Leech, Geoffrey N. (1988 (1983)) The Principles of Pragmatics. London: Longman.

Levinson, Stephen C. (1983) Pragmatics. Cambridge: Cambridge University Press.

Levinson, Stephen C. (2000) Presumptive Meanings: The Theory of Generalized Conversational Implicature. Cambridge, MA: The MIT Press, Bradford.

Lorenzer, Alfred (1972) Zur Begründung einer materialistischen Sozialisationstheorie. Frankfurt/Main: Suhrkamp.

Lorenzer, Alfred (1973) Über den Gegenstand der Psychoanalyse oder: Sprache und Interaktion. Frankfurt/Main: Suhrkamp.

Lorenzer, Alfred (1974) Die Wahrheit der psychoanalytischen Erkenntnis: Ein historisch-materialistischer Entwurf. Frankfurt/Main: Suhrkamp.

Luhmann, Niklas (2000 (1984)) Sociale systemer. København: Hans Reitzels Forlag.

MacFarlane, John (2014) Assessment Sensitivity: Relative Truth and its Applications. Oxford: Oxford university Press.

Malinowski, Bronislaw (2014 (1922)) Argonauts of the Western Pacific. London \& New York: Routledge.

Marx, Karl (1974 (1857-1858)) Grundrids til kritikken af den politiske øko- 


\section{Peter Widell}

nomi. København: Rhodos.

Mead, George Herbert (2005 (1934)) Sindet, selvet og samfundet. København: Akademisk Forlag.

Mill, John Stuart (2012 (1863)) A System of Logic. CreateSpace Independent Publishing Platform

Noonan, Harold W. (2003 (1989)) Personal Identity. London: Routledge.

Nucci, Larry P. (2001) Education in the Moral Domain. Cambridge: Cambridge University Press.

Nucci, Larry P. \& Narcia Navaez (2008) (eds.) Handbook of Moral and Character Education. New York \& Oxford: Routledge.

Parfit, Derek (1976) 'Personal Identity', In: J. Glover (ed.) The Philosophy of Mind. Oxford: Oxford University Press:142-62.

Parfit, Derek (1984) Reasons and Persons. Oxford.

Parsons, Talcott (1961 (1937)) The Structure of Social Action. New York: Free Press.

Peirce, Charles Sanders (1997 (1903)) The 1903 Harvard Lectures on Pragmatism. Albany, NY: SUNY Press.

Perry, John (ed.) (1975) Personal Identity. Berkeley and Los Angeles: University of California Press.

Perry, John (2002) Identity, Personal Identity, and the Self. Hackett Publishing Co, Inc.

Piaget, Jean (1953 (1936)) The Origin of Intelligence in the Child. London: Routledge \& Kegan Paul.

Piaget, Jean \& Bärbel Inhelder (1971 (1966)) Barnets Psykologi. København: Hans Reitzels Forlag.

Preyer, Gerhard \& Georg Peter (eds.) (2005) Contextualism in Philosophy: Knowledge, Meaning, and Truth. Oxford and New York: Oxford University Press.

Preyer, Gerhard \& Georg Peter (eds.) (2007) Context-Sensivity and Semantic Minimalism: New Essays on Semantics and Pragmatics. Oxford: Oxford University Press.

Ramsey, Frank P. (1927) 'Facts and Propositions', Proceedings of the Aristotelian Society Suppl. 7

Récanati, François (2003) Literal Meaning: The Very Idea. Cambridge: Cambridge University Press.

Recanati, Francois (2007) Perspectival Thought: A Plea for (Moderate) Relativism. Oxford: Oxford University Press.

Recanati, Francois (2011) Truth-Conditional Pragmatics. Oxford: Oxford University Press.

Rizzolatti, Giacomo \& Laila Craighero (2004) 'The Mirror-Neuron System', Annual Review of Neuroscience 27:169-192.

Rorty, Richard (ed.) (1992 (1967)) The Linguistic Turn. Chicago: University of Chicago Press.

Russell, Bertrand (1905) 'On Denoting', Mind 14:479-93. 


\section{Sprog og identitet: En oversigt}

Sacks, Harvey, Emanuel A. Schegloff \& Gail Jefferson (1974) 'A simplest systematics for the organization of turn-taking in conversation', Language 50, 4:696-735.

Sapir, Edward (1921) Language. New York: Harcourt, Brace.

Saussure, Ferdinand de (1970 (1916)) Kurs i allmän lingvistik. Stockholm: Bo Cavefors Bokförlag.

Schriffrin, Deborah (2006) In Other Words: Variation in Reference and Narrative. Cambridge: Cambridge University Press.

Schutz, Alfred (1973 (1932)) Hverdagslivets sociologi. København: Hans Reitzels Forlag.

Searle, John R. (1969) Speech Acts: An Essay in the Philosophy of Language. Cambridge: Cambridge University Press.

Searle, John R. (1971 (1965)) 'What Is a Speech Act?', In: John R. Searle (ed.) The Philosophy of Language (Dansk duplikat 1977). Oxford: Oxford University Press:39-53.

Searle, John R. (1979a (1975)) 'Indirect Speech Acts', In: Searle, John R. Expression and Meaning. Cambridge: Cambridge University Press:30-57.

Searle, John R. (1979b (1975)) 'Literal Meaning', In: Searle, John R. Expression and Meaning. Cambridge: Cambridge University Pres:117-136.

Searle, John R. (1981) 'Minds, Brains and Programs', In: John Haugeland (ed.) Mind Design; Philosophy, Psychology, Artificial Intelligence. Cambridge, MA: The MIT Press: 282-306.

Searle, John R. (1983) Intentionality. Cambridge: Cambridge University Press.

Searle, John R. (1984) Minds, Brains and Science: The 1984 Reith Lectures. London: British Broadcasting Corporation.

Searle, John R. (1995) The Construction of Social Reality. London: Allen Lane, The Penguin Press.

Searle, John R. (2010) Making the Social World: The Structure of Human Civilization. Oxford: Oxford University Press.

Shoemaker, Sidney \& Richard Swinburne (1984) Personal Identity. Oxford: Blackwell Publishers.

Sidnell, Jack \& Tanya Stivers (eds.) (2012) The Handbook of Conversation Analysis. New York: Wiley-Blackwell.

Simons, Herbert W. (ed.) (1988a) Rhetotic in the Human Sciences. London: SAGE Publications.

Simons, Herbert W. (1988b) The Rhetorical Turn: Invention and Persuasion in the Conduct of Inquiry. Chicago: University of Chicago Press.

Soames, Scott (2010a) Philosophy of Language. Princeton and Oxford: Princeton University Press.

Soames, Scott (2010b) What is Meaning? Princeton and Oxford: Princeton University Press. 


\section{Peter Widell}

Sperber, Dan \& Deirdre Wilson (1986) Relevance: Communication and Cognition. Oxford: Basil Blackwell.

Strawson, Galen (2005) The Self? New York: John Wiley \& Sons.

Strawson, Peter F. (1959) Individuals: An Essay in Descriptive Metaphysics. London: Methuen.

Strawson, Peter F. (1997) Entity and Identity. Oxford: Oxford University Press.

Szabó, Zoltán Gendler (ed.) (2005) Semantic versus Pragmatics. Oxford: Clarendon Press.

Talmy, Leonard (1988) 'Force Dynamics in Language and Cognition', Cognitive Science 12:49-100.

Talmy, Leonard (2000) Toward a Cognitive Semantics. Cambridge, MA: The MIT Press.

Tannen, Deborah, Heidi E. Hammilton, Deborah Schiffrin (ed.) (2015) The Handbook of Discourse Analysis. New York: Wiley-Blackwell.

Tomasello, Michael (1999) The Cultural Origins of Human Cognition. Cambridge, MA: Harvard University Press.

Tomasello, Michael (2003) Constructing a Language: A Usage-Based Theory of Language Acquisition. Cambridge, MA: Harvard University Press.

Tomasello, Michael (2014) The Natural History of Human Thinking. Cambridge, MA: Harvard University Press.

Toumela, Raimo (1984) Theory of Social Action. Dordrecht-Holland: D. Reidel Publishing Company.

Toumela, Raimo (2000) Cooperation: A Philosophical Study. Dordrecht: Kluwer.

Toumela, Raimo (2013) Social Ontology: Collective Intentionality and Group Agents. Oxford: Oxford University Press.

Travis, Charles (1986) Meaning and Interpretation. Oxford: Blackwell.

Turiel, Elliot (1983) The Development of Social Knowledge: Morality and Convention. Cambridge: Cambridge University Press.

Turiel, Elliot (2002) The culture of Morality: Social Development, Context, and Conflict. Cambridge: Cambridge University Press.

Turner, Mark (2007) The Meaning of the Body: Aesthetics of Human Understanding. Chicago: University of Chicago Press.

van Dijk, Teun A. (ed.) (1996a) Discourse as Structure and Process - Discource Studies: A Multidisciplinary Introduction vol. I. London: SAGE Publications.

van Dijk, Teun A. (ed.) (1996b) Discourse as Social Interaction - Discource Studies: A Multidisciplinary Introduction vol. II. London: SAGE Publications.

Vygotsky, Lev Semenovich (1974 (1934)) Tcenkning og sprog 2. København: Hans Reitzels Forlag. 


\section{Sprog og identitet: En oversigt}

Whorf, Benjamin Lee (1956) Language, Thought, and Reality. Cambridge, Massachusetts: MIT Press.

Widell, Peter (2009) Logik, mening, handling, tale. I Inger Schoonderbeek Hansen \& Peter Widell (udg.): 12. Møde om Udforskningen af Dansk Sprog, Arhus 2008:301-318.

Wittgenstein, Ludwig (1963 (1923)) Tractatus Logico-Philosophicus. København: Gyldendal.

Wittgenstein, Ludwig (1971 (1953)) Filosofiske undersøgelser. København: Munksgaard. 